\title{
Spray Pyrolysis Deposition of Nanostructured Tin Oxide Thin Films
}

\author{
G. E. Patil, ${ }^{1}$ D. D. Kajale, ${ }^{2}$ V. B. Gaikwad, ${ }^{1}$ and G. H. Jain ${ }^{1}$ \\ ${ }^{1}$ Materials Research Laboratory, K.T.H.M. College, Nashik 422 005, India \\ ${ }^{2}$ Materials Research Laboratory, Arts, Commerce and Science College, Nandgaon 423 106, India
}

Correspondence should be addressed to G. H. Jain, gotanjain@rediffmail.com

Received 17 April 2012; Accepted 25 June 2012

Academic Editors: K. Ray and L. Xu

Copyright (C) 2012 G. E. Patil et al. This is an open access article distributed under the Creative Commons Attribution License, which permits unrestricted use, distribution, and reproduction in any medium, provided the original work is properly cited.

\begin{abstract}
Nanostructured $\mathrm{SnO}_{2}$ thin films were grown by the chemical spray pyrolysis (CSP) method. Homemade spray pyrolysis technique is employed to prepare thin films. $\mathrm{SnO}_{2}$ is wide bandgap semiconductor material whose film is deposited on glass substrate using aqueous solution of $\mathrm{SnCl}_{4} \cdot 5 \mathrm{H}_{2} \mathrm{O}$ as a precursor. XRD (X-ray diffraction), UV (ultraviolet visible spectroscopy), FESEM (field emission scanning electron microscopy), and EDS (energy dispersive spectroscopy) analysis are done for structural, optical, surface morphological, and compositional analysis. XRD analysis shows polycrystalline nature of samples with pure phase formation. Crystallite size calculated from diffraction peaks is $29.92 \mathrm{~nm}$ showing nanostructured thin films. FESEM analysis shows that $\mathrm{SnO}_{2}$ thin film contains voids with nanoparticles. EDS analysis confirms the composition of deposited thin film on glass substrate. UVvisible absorption spectra show that the bandgap of $\mathrm{SnO}_{2}$ thin film is $3.54 \mathrm{eV}$. Bandgap of $\mathrm{SnO}_{2}$ thin film can be tuned that it can be used in optical devices.
\end{abstract}

\section{Introduction}

The tin oxide is a wide bandgap semiconductor (energy bandgap $3.6 \mathrm{eV}$ ), and it has only the tin atom that occupies the centre of a surrounding core composed of six oxygen atoms placed approximately at the corners of a quasiregular octahedron (Figure 1). In the case of oxygen atoms, three tin atoms surround each of them, forming an almost equilateral triangle. The lattice parameters are $a=b=4.737 \AA$ and $c=3.186 \AA[1]$.

$\mathrm{SnO}_{2}$ is a special oxide material because it has a low electrical resistance with high optical transparency in the visible range. Due to these properties, apart from gas sensors, $\mathrm{SnO}_{2}$ is being used in many other applications, such as electrode materials in solar cells, light-emitting diodes, flat-panel displays, and other optoelectronic devices where an electric contact needs to be made without obstructing photons from either entering or escaping the optical active area and in transparent electronics, such as transparent fieldeffect transistors $[2,3] . \mathrm{SnO}_{2}$ owing to a wide bandgap is an insulator in its stoichiometric form. However, due to the high intrinsic defects, that is oxygen deficiencies, tin oxide $\left(\mathrm{SnO}_{2-X}\right)$ possesses a high conductivity. It has been shown that the formation energy of oxygen vacancies and tin interstitials in $\mathrm{SnO}_{2}$ is very low. Therefore, these defects form readily, which explains the high conductivity of pure, but nonstoichiometric, tin oxide.

$\mathrm{SnO}_{2}$ thin films have been deposited using different techniques, such as spray pyrolysis [4], sol-gel process $[5,6]$, chemical vapour deposition [7], sputtering [8], and pulsedlaser deposition [9]. In the present investigation, the authors have used the spray pyrolysis technique to prepare thin films of $\mathrm{SnO}_{2}$ because the technique is simple and involves lowcost equipments and raw materials. Moreover, the deposition rate and the thickness of the films can be easily controlled over a wide range by changing the spray parameter. The technique involves a simple technology in which an ionic solution (containing the constituent elements of a compound in the form of soluble salts) is sprayed over heated substrates. Though a number of tin salts are available for this purpose, the most suitable is one whose decomposition temperature is not very high, the decomposition reaction leading to the formation of $\mathrm{SnO}_{2}$ is thermodynamically feasible, and no residue of the reactants is left behind in 


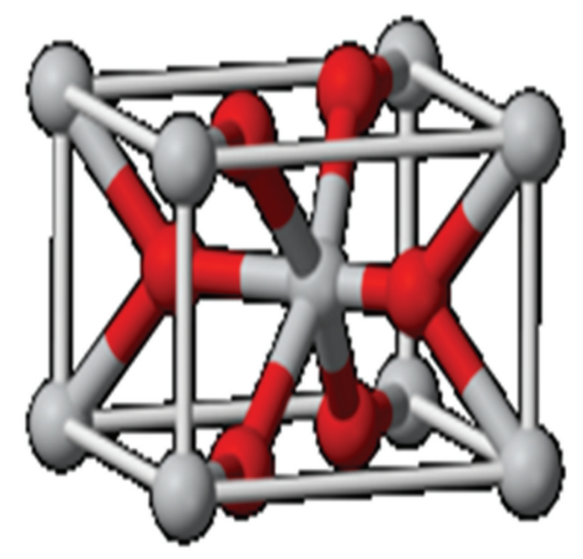

Figure 1: The rutile structure of $\mathrm{SnO}_{2}$, which contains tin atoms at the corners and center of the unit cell.

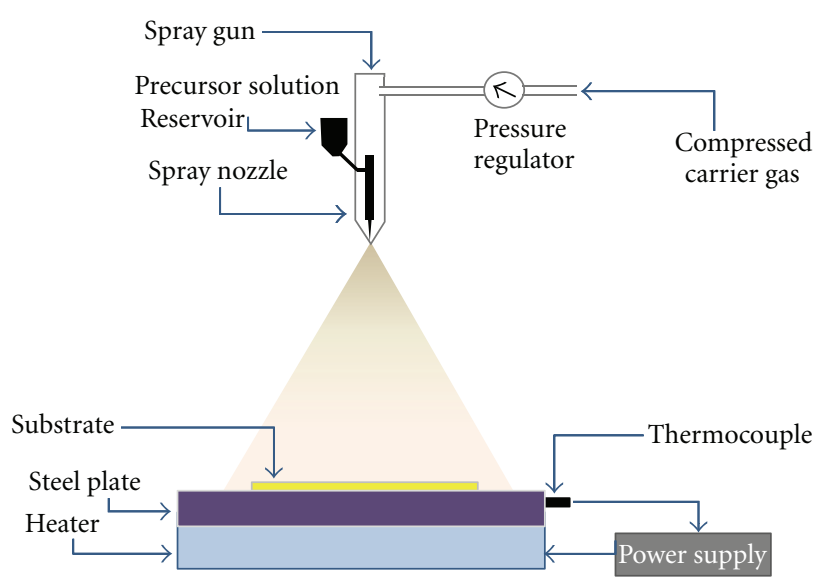

FIGURE 2: The scheme of the spray pyrolysis setup.

the deposited material [10]. Keeping these in view, we have used an aqueous solution of $\mathrm{SnCl}_{4} \cdot 5 \mathrm{H}_{2} \mathrm{O}$ as the precursor solution for spray pyrolysis in the present investigation. In this paper, we report the synthesis and characterization of nanostructured tin oxide thin films.

\section{Experimental}

$\mathrm{SnO}_{2}$ thin films were deposited by the CSP technique from aqueous solutions containing $0.1 \mathrm{M}$ tin chloride pentahydrate as a precursor, using compressed air as a carrier gas. A homemade assembly has been used to prepare thin film as described elsewhere [11]. Ultrasonically cleaned glass slides cut in small pieces are used as a substrate on which films are grown. Cleaned glass slides were then placed on a solid uniform thermal conductor surface to provide proper heating with uniformity to films. A heater is used as heat source to provide temperature of around $250^{\circ} \mathrm{C}$. After spraying, films on glass slides were sintered at $550^{\circ} \mathrm{C}$ for $30 \mathrm{~min}$ inside the furnace. Total volume of the solution sprayed was $20 \mathrm{~mL}$. The various process parameters in the

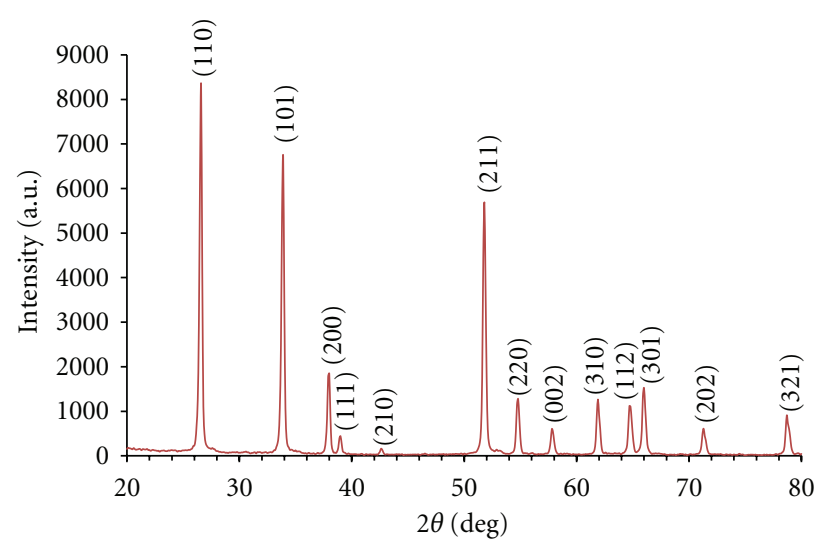

Figure 3: X-ray diffraction pattern of $\mathrm{SnO}_{2}$ thin film on glass substrate.

TABle 1: Process parameters for the spray deposition of the films.

\begin{tabular}{lc}
\hline Spray parameters & Optimum value/item \\
\hline Nozzle & Glass \\
Nozzle-substrate distance & $25 \mathrm{~cm}$ \\
$\mathrm{SnCl}_{4} \cdot 5 \mathrm{H}_{2} \mathrm{O}$ solution concentration & $0.1 \mathrm{M}$ \\
Solvent & Distilled water \\
Solution flow rate & $4 \mathrm{~mL} / \mathrm{min}$ \\
Carrier gas & Compressed air \\
Substrate temperature & $250^{\circ} \mathrm{C}$ \\
\hline
\end{tabular}

film deposition are listed in Table 1. The scheme of the spray pyrolysis setup used in this study is presented in Figure 2.

The deposited thin films were characterized by Xray diffraction (XRD), scanning electron microscopy (SEM), optical absorption spectra, and energy dispersivespectroscopy (EDS) measurements. X-ray diffraction pattern was recorded on diffractometer (Miniflex Model, Rigaku, Japan) using $\mathrm{CuK}_{\alpha}$ radiation with a wavelength $\lambda=1.5418 \AA$ at $2 \theta$ values between $20^{\circ}$ and $80^{\circ}$. The average crystallite size $(D)$ was estimated using the Scherrer equation [12] as follows: $D=0.9 \lambda / \beta \cos \theta$, where $\lambda, \beta$, and $\theta$ are the $\mathrm{X}$-ray wavelength, the full width at half maximum (FWHM) of the diffraction peak, and Braggs diffraction angle, respectively. A Hitachi S-4800 model was used to examine the surface morphology of the sample by FESESM and the percentage of constituent elements was evaluated by the energy dispersive $\mathrm{X}$-rays analysis (EDX) technique. The optical absorption spectra of the films were measured in the wavelength range of 200-700 nm on a Shimadzu UV-2450 spectrophotometer.

\section{Results and Discussion}

Figure 3 shows X-ray diffraction pattern of the $\mathrm{SnO}_{2}$ thin films. XRD pattern is compared with JCPDS standard database [13], which confirms the formation of $\mathrm{SnO}_{2}$. XRD pattern of $\mathrm{SnO}_{2}$ thin film deposited over glass substrate shows polycrystalline phases with calculated $h, k, l$ indices (110), (101), (200), (111), (210), (211), and so forth, corresponding to peak positions $26.60,33.90,38.0,39.00$, 


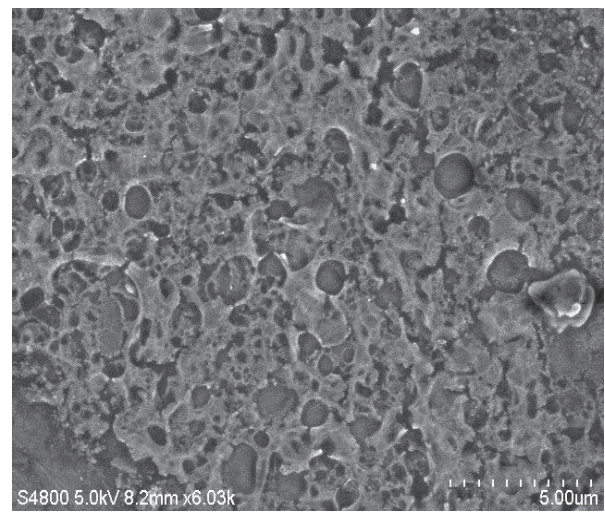

(a)

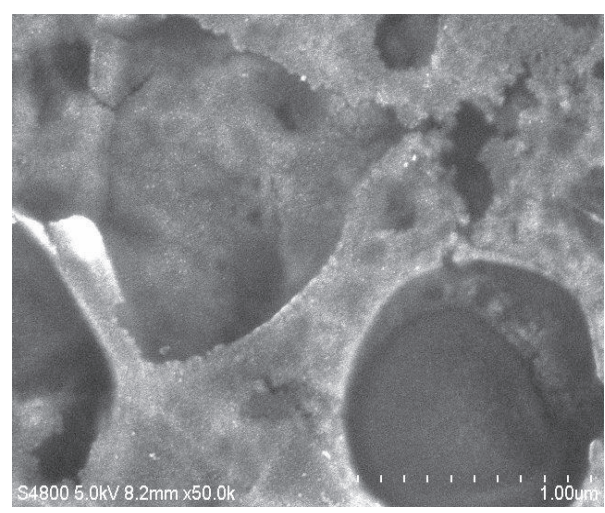

(c)

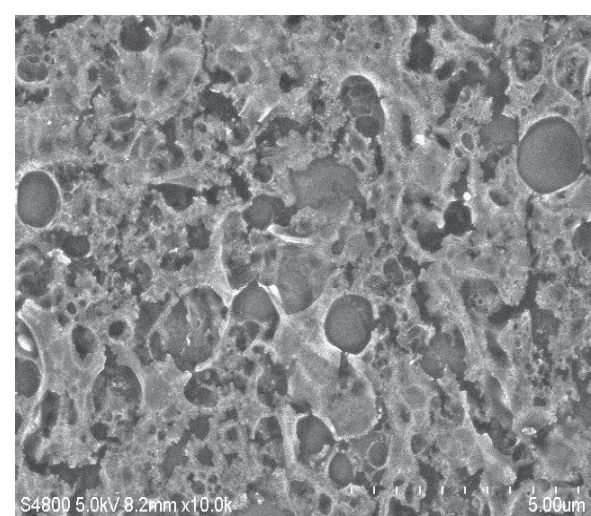

(b)

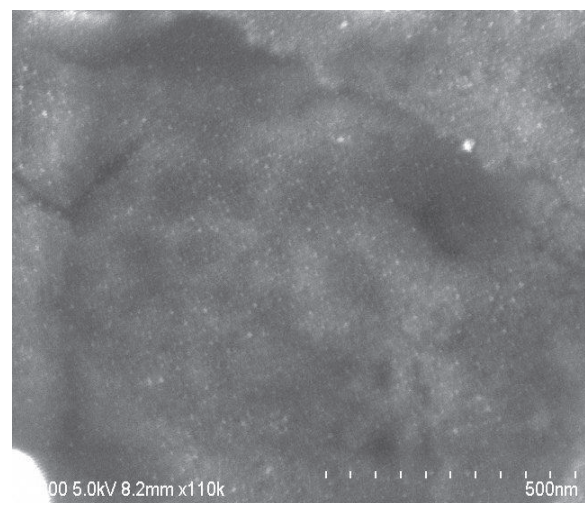

(d)

Figure 4: FESEM micrograph of $\mathrm{SnO}_{2}$ thin film at different spots (a-b) and with different magnification (c-d).

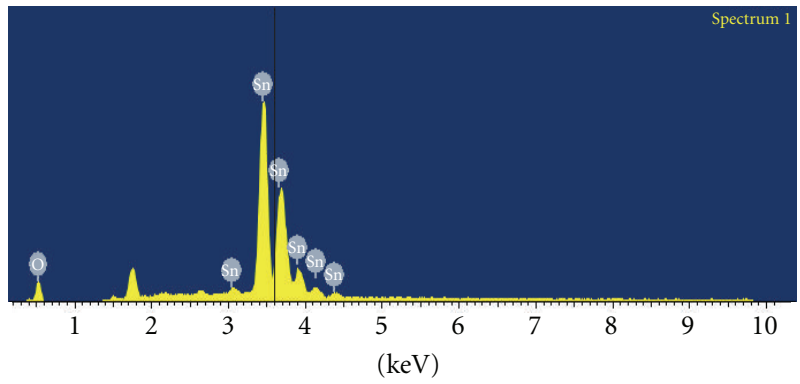

Full-scale 2378 cts cursor: 3.606 (396 cts)

FIGURE 5: EDS pattern of $\mathrm{SnO}_{2}$ thin film deposited on glass substrate.

42.60, and 513.80 as shown in Table 2. Crystal structure of $\mathrm{SnO}_{2}$ thin film is cassiterite and the average crystallite size calculated from diffraction peaks is $29.92 \mathrm{~nm}$.

Figures 4(a) and 4(d) show FESEM micrograph of $\mathrm{SnO}_{2}$ thin film at different spots and magnification. Deposited thin film shows pores on surface containing nanoparticles. Figure 4(d) shows the particles in pores.

Figure 5 shows EDS pattern of tin oxide thin film EDS analysis confirms the composition of deposited thin film on glass substrate for the sample. Stoichiometrically expected at

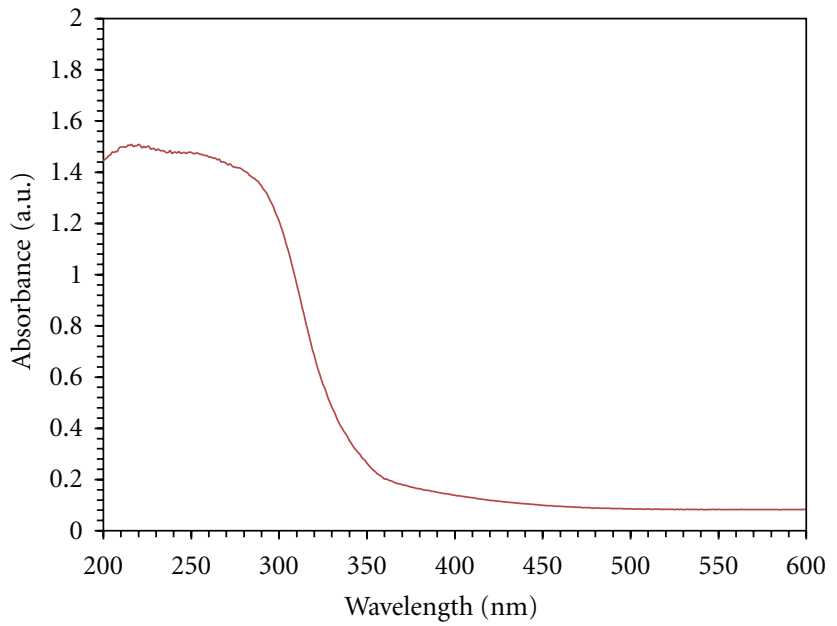

FIgURE 6: Optical absorbance spectra $\mathrm{SnO}_{2}$ thin film.

$\%$ of $\mathrm{Sn}$ and $\mathrm{O}$ is 33.3 and 66.7 , respectively. Observed at $\%$ of $\mathrm{Sn}$ and $\mathrm{O}$ is 28.25 and 71.75 , respectively. There is little deviation from stoichiometry of the prepared film.

Figure 6 shows optical absorbance spectrum of $\mathrm{SnO}_{2}$ thin film. The bandgap energy calculated from the absorption spectra is $3.54 \mathrm{eV}$ which is exactly matching with reported bandgap energy $(3.6 \mathrm{eV})$ of $\mathrm{SnO}_{2}[14,15]$. 
TABLE 2: X-ray diffraction analysis of the $\mathrm{SnO}_{2}$ thin films.

\begin{tabular}{|c|c|c|c|c|}
\hline$(h k l)$ planes & Angle, $2 \theta$ (degree) & $d$ spacing $(\AA)$ & FWHM & Crystallite size $(\mathrm{nm})$ \\
\hline$\left(\begin{array}{lll}1 & 1 & 0\end{array}\right)$ & 26.60 & 3.3484 & 0.163 & 34 \\
\hline$\left(\begin{array}{lll}1 & 0 & 1\end{array}\right)$ & 33.90 & 3.6422 & 0.171 & 33 \\
\hline$\left(\begin{array}{lll}2 & 0 & 0\end{array}\right)$ & 38.00 & 2.3660 & 0.190 & 32 \\
\hline$\left(\begin{array}{lll}1 & 1 & 1\end{array}\right)$ & 39.00 & 2.3076 & 0.182 & 30 \\
\hline$\left(\begin{array}{lll}2 & 1 & 0\end{array}\right)$ & 42.60 & 2.1206 & 0.130 & 28 \\
\hline$\left(\begin{array}{lll}2 & 1 & 1\end{array}\right)$ & 51.80 & 1.7635 & 0.159 & 32 \\
\hline$\left(\begin{array}{lll}2 & 2 & 0\end{array}\right)$ & 54.80 & 1.6738 & 0.185 & 30 \\
\hline$\left(\begin{array}{lll}0 & 0 & 2\end{array}\right)$ & 57.80 & 1.5939 & 0.126 & 29 \\
\hline$\left(\begin{array}{lll}3 & 1 & 0\end{array}\right)$ & 61.90 & 1.4978 & 0.150 & 30 \\
\hline$\left(\begin{array}{lll}1 & 1 & 2\end{array}\right)$ & 64.80 & 1.4376 & 0.223 & 26 \\
\hline$\left(\begin{array}{lll}3 & 0 & 1\end{array}\right)$ & 66.00 & 1.4143 & 0.174 & 30 \\
\hline$\left(\begin{array}{lll}2 & 0 & 2\end{array}\right)$ & 71.30 & 1.3216 & 0.168 & 28 \\
\hline$\left(\begin{array}{lll}3 & 2 & 1\end{array}\right)$ & 78.70 & 1.2149 & 0.132 & 27 \\
\hline
\end{tabular}

\section{Conclusions}

In this study, we showed that $\mathrm{SnO}_{2}$ thin films could be successfully deposited by the low-cost chemical spray pyrolysis method in air, using aqueous solutions containing $\mathrm{SnCl}_{4} \cdot 5 \mathrm{H}_{2} \mathrm{O}$.

(i) Homemade spray pyrolysis technique is a cheap and easy method to prepare thin films.

(ii) Crystallite size calculated from diffraction peaks is $29.92 \mathrm{~nm}$ showing nanostructured thin film formation.

(iii) FESEM studies film shows pores on surface containing nanoparticles and EDS analysis confirms purity of film.

(iv) Bandgap of $\mathrm{SnO}_{2}$ can be tuned that it can be used in optical devices.

\section{Acknowledgments}

The financial support for this work from DST, New Delhi through INSPIRE fellowship for doctoral degree is gratefully acknowledged. The authors thank The Principal of the KTHM College, Nashik, and Principal of the Arts, Commerce and Science College, Nandgaon, for providing the experimental facilities. The authors thank Director of the CMET, Pune, for providing the FESEM facility.

\section{References}

[1] R. B. Vasiliev, M. N. Rumyantseva, S. E. Podguzova, A. S. Ryzhikov, L. I. Ryabova, and A. M. Gaskov, "Effect of interdiffusion on electrical and gas sensor properties of $\mathrm{CuO} / \mathrm{SnO}_{2}$ heterostructure," Materials Science and Engineering $B$, vol. 57, no. 3, pp. 241-246, 1999.

[2] J. F. Wager, "Transparent electronics," Science, vol. 300, no. 5623, pp. 1245-1246, 2003.
[3] R. L. Hoffman, B. J. Norris, and J. F. Wager, "ZnO-based transparent thin-film transistors," Applied Physics Letters, vol. 82, no. 5, article 733, 3 pages, 2003.

[4] S. D. Shinde, G. E. Patil, D. D. Kajale, V. B. Gaikwad, and G. $\mathrm{H}$. Jain, "Synthesis of $\mathrm{ZnO}$ nanorods by spray pyrolysis for $\mathrm{H}_{2} \mathrm{~S}$ gas sensor," Journal of Alloys and Compounds, vol. 528, pp. 109-114, 2012.

[5] C. Cobianu, C. Savaniu, P. Siciliano, S. Capone, M. Utriainen, and L. Niinisto, " $\mathrm{SnO}_{2}$ sol-gel derived thin films for integrated gas sensors," Sensors and Actuators B, vol. 77, no. 1-2, pp. 496502, 2001.

[6] R. Rella, P. Siciliano, S. Capone, M. Epifani, L. Vasanelli, and A. Licciulli, "Air quality monitoring by means of sol-gel integrated tin oxide thin films," Sensors and Actuators B, vol. 58, no. 1-3, pp. 283-288, 1999.

[7] R. Larciprete, E. Borsella, P. De Padova, P. Perfetti, G. Faglia, and G. Sberveglieri, "Organotin films deposited by laserinduced CVD as active layers in chemical gas sensors," Thin Solid Films, vol. 323, no. 1-2, pp. 291-295, 1998.

[8] G. Sberveglieri, G. Faglia, S. Groppelli, and P. Nelli, "Methods for the preparation of $\mathrm{NO}, \mathrm{NO}_{2}$ and $\mathrm{H}_{2}$ sensors based on tin oxide thin films, grown by means of the r.f. magnetron sputtering technique," Sensors and Actuators B, vol. 8, no. 1, pp. 79-88, 1992.

[9] R. Dolbec, M. A. El Khakani, A. M. Serventi, and R. G. SaintJacques, "Influence of the nanostructural characteristics on the gas sensing properties of pulsed laser deposited tin oxide thin films," Sensors and Actuators B, vol. 93, no. 1-3, pp. 566571, 2003.

[10] G. E. Patil, D. D. Kajale, D. N. Chavan et al., "Synthesis, characterization and gas sensing performance of $\mathrm{SnO}_{2}$ thin films prepared by spray pyrolysis," Bulletin of Materials Science, vol. 34, no. 1, pp. 1-9, 2011.

[11] P. Ramesh Kumar, N. Khan, S. Vivekanandhan, N. Satyanarayana, A. K. Mohanty, and M. Misra, "Nanofibers: effective generation by electrospinning and their applications," Journal of Nanoscience and Nanotechnology, vol. 12, no. 1, pp. 1-25, 2012.

[12] B. D. Cillity, Elements of X-Ray Diffraction, Addison-Wesley, 2nd ed edition, 1956.

[13] JCPDS data card no. 41-1445. 
[14] K. Kant, D. Losic, and R. E. Sabzi, “Template synthesis of nickel, cobalt, and nickel hexacyanoferrate nanodot, nanorod, and nanotube arrays," International Journal of Nanoscience, vol. 10, no. 1-2, pp. 1-6, 2011.

[15] G. E. Patil, D. D. Kajale, S. D. Shinde, V. B. Gaikwad, and G. H. Jain, "Synthesis and characterization of $\mathrm{SnO}_{2}$ nanoparticles by hydrothermal route," International Nano Letters, vol. 2, p. 46, 2012. 

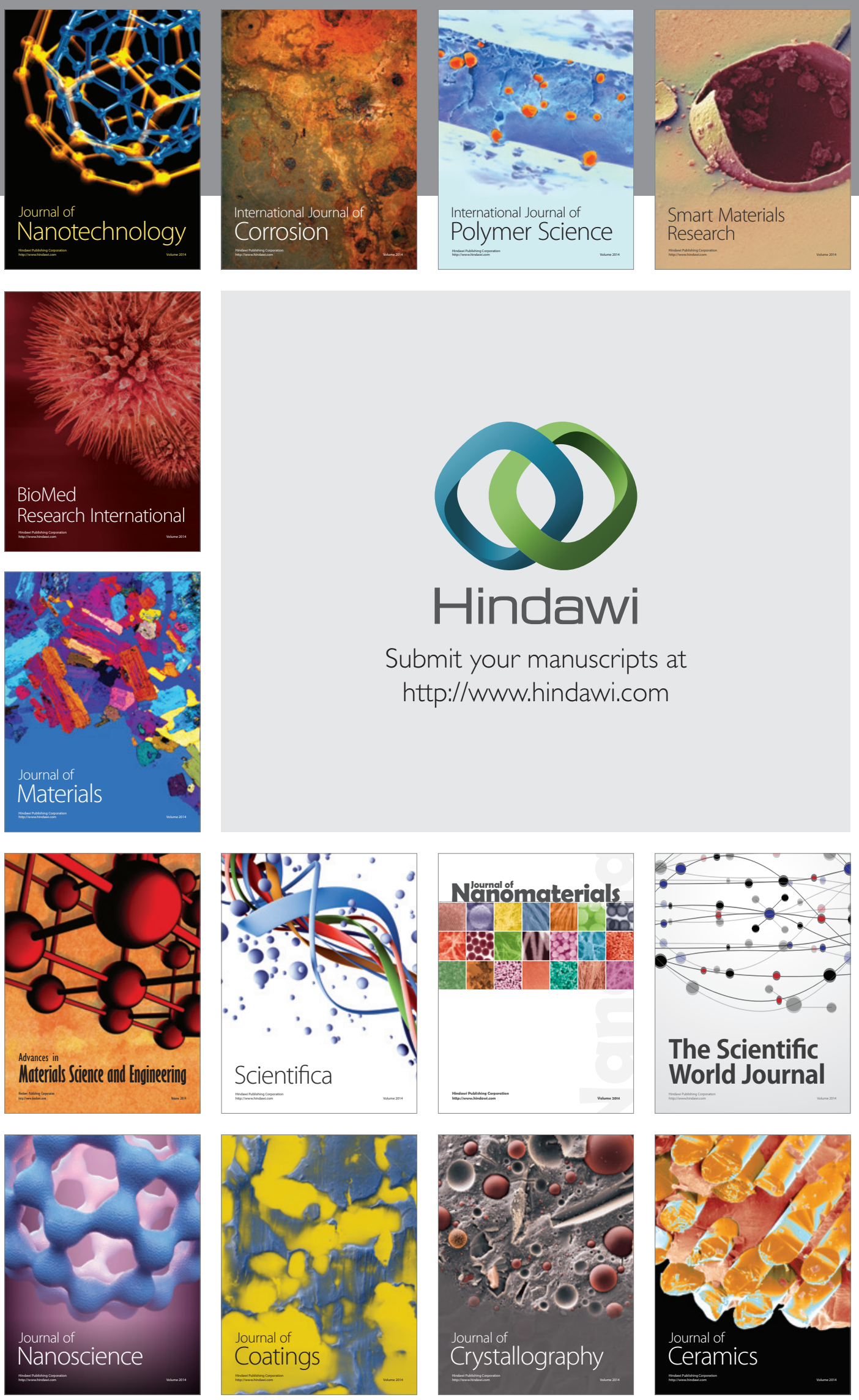

The Scientific World Journal

Submit your manuscripts at

http://www.hindawi.com

\section{World Journal}

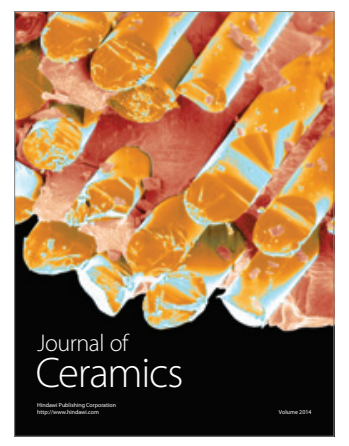

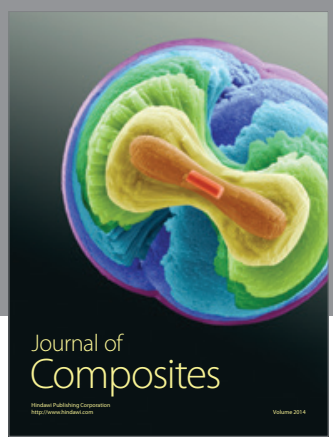
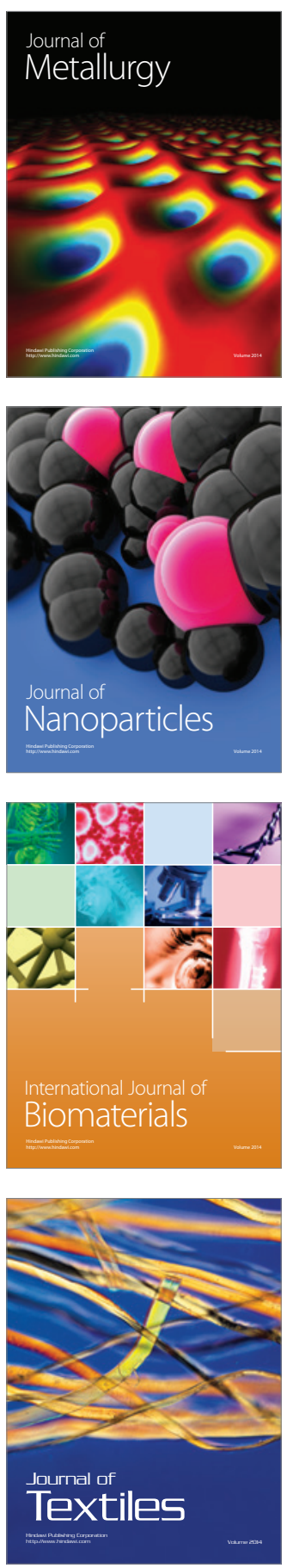